\title{
The optimization of transfection in MCF-7 cells combining ultrasound irradiation with contrast agent and polyethyleneimine
}

\author{
Zhi-Yi Chen ${ }^{1 *}$, Ri-Xiang Qiu ${ }^{2 *}$, Xiao-Fang Sun ${ }^{3}$, Kun Liang ${ }^{3}$, Jin-Shan Zhang ${ }^{4}$, Yan Lin ${ }^{1}$ and Feng Yang ${ }^{1}$ \\ Correspondence: winchen@vip.126.com \\ ${ }^{1}$ Department of Medical Ultrasound, The Third Affiliated Hospital of Guangzhou Medical University, Guangzhou 510150, China. \\ 2 Department of Pharmacy, The Third Affiliated Hospital of Guangzhou Medical University, Guangzhou 510150, China. \\ ${ }^{3}$ Guangzhou Research Institute of Obstetrics and Gynecology, Key Laboratory for Major Obstetric Diseases of Guangdong Province, \\ The Third Affiliated Hospital of Guangzhou Medical University, Institute of Obstetrics and Gynecology, Guangzhou 510150, China. \\ ${ }^{4}$ Department of Nuclear Medicine, The Third Affiliated Hospital of Guangzhou Medical University, Guangzhou 510150, China.
}

\begin{abstract}
Objective: To enhance the transfection efficiency of the human breast cancer cell lines (MCF-7) cells by plasmid DNA, the optimized condition and synergistic role of ultrasound (US) irradiation with contrast agent and polyethyleneimine (PEI) were discussed.

Methods: MCF-7 cells were transfected with the compounds prepared by the plasmid DNA encoding luciferase (pCMV-luciferase-GL3) and PEI. Meanwhile, SonoVue microbubble was added to the cell suspension to serve as nucleation sites for acoustic cavitation before US irradiation. Then, the DNA expression of luciferase plasmid and viability of cells were evaluated through optimizing US irradiation. Furthermore, the influencing factor, such as the concentration of plasmid, incubation time, serum, the type of solvent and the volume of culture media, were analyzed.

Results: The viability of cells and US-induced enhancement of luciferase activity were influenced by the US intensity, exposure time and duty cycle. US irradiation under an appropriate condition could accelerate the permeation of the PEI/DNA complex through the cell membrane. It could enhance the transfection efficiency of plasmid DNA. The optimal US condition for the enhancement was determined to be $1 \mathrm{~W} / \mathrm{cm}^{2}, 10 \% \mathrm{DC} \mathrm{for} 3 \mathrm{mins}$. In contrast to the PEI/DNA complex alone without US irradiation or US irradiation alone, the combination of US irradiation with contrast agent and PEI had a significantly enhanced luciferase activity $(\mathrm{P}<0.01)$. The 2 hrs preirradiation incubation with PEI/DNA complex for MCF-7 cells exhibited a significantly enhanced luciferase activity $(\mathrm{P}<0.01)$. In addition, the transfection efficiency was also affected by serum, type of solvent and the volume of culture media.

Conclusions: These results suggest that optimized parameters of US and transfection enhance the efficiency of gene expression in MCF-7 cells apparently. The combination of US irradiation with contrast agent and PEI has a synergy and it is not only a simple but also an applied promising method to increase plasmid DNA expression.
\end{abstract}

Key words: Ultrasound, contrast agent, polyethyleneimine, transfectionm cancer, cell

\section{Background}

Polyethyleneimine (PEI) is one of the most promising non-viral vectors $[1,2]$. Plasmid DNA and PEl complexation could enhance the transfection efficiency, but it should be enhanced further, and the cytotoxicity should be reduced more. In order to improve the transfection efficiency of non-viral vector, effective physical stimulations, such as ultrasound (US) irradiation, could be used to increase the cellular uptake and gene expression. In non-viral transgenic technologies, ultrasound targeted microbubble destruction (UTMD) is a simple, non-invasive method. The transitory increase of membrane permeability caused by the UTMD could transport exogenous molecules into cells. This method which is non-toxic and non-immunogenic has been successfully applied in both in vivo and in vitro gene therapy studies [3-6]. It is safer than other methods, so it may be applied in clinical application in the near future. Although the combination of US irradiation with polyethyleneimine (PEI) has already been investigated by some other groups [7,8], the transfer efficiency is still relatively low and the optimization of transfection conditions has not been studied yet. Both PEI and UTMD are promising transfection methods and novel work, but there are little reports on systematic research about

(C) 2012 Chen et al; licensee Herbert Publications Ltd. This is an open access article distributed under the terms of Creative Commons Attribution License (http://creativecommons.org/licenses/by/3.0), This permits unrestricted use, distribution, and reproduction in any medium, provided the original work is properly cited. 
these two methods. Therefore, we optimized the parameters of US exposure and transfection, and explored whether the combination of these two methods could improve the transfection efficiency synergistically. These two methods were combined and the influence on the cell vitality of human breast cancer cell lines (MCF-7) and its gene expression underling different US irradiation strategies and transfection parameters were compared.

\section{Materials and methods}

Preparation of Plasmid DNA pCMV-luciferase-GL3 (7.4 kb) was constructed by cloning the luciferase gene from the pGL3-Promoter Vector (5.01 kb, Promega Corp., Madison, WI, USA) into pcDNA3.1 (5.42 kb, Invitrogen, San Diego, CA, USA) at the Bam HI and Hind III sites [9]). The concentration of isolated plasmid DNA was determined by absorbance at 260 nm wavelength (A260) using UV spectrophotometry (DU-640, Beckman Coulter, Fullerton, CA, USA) and resuspended to a final concentration of $1 \mu \mathrm{g} / \mu \mathrm{l}$ in buffer.

\section{Preparation of transfection complexes}

Branched PEl with an average molecular weight of $25 \mathrm{kDa}$ was obtained from Sigma-Aldrich (St. Louis, MO, USA). An aqueous stock solution of PEI was prepared by diluting $1 \mathrm{mg}$ of the commercial solution in $1000 \mathrm{ml}$ deionize water, neutralized with $\mathrm{HCl}$ and filtering at $0.2 \mu \mathrm{m}$ (Millipore, Bedford, MA, USA). PEI/DNA complexes were performed by mixing PEI and plasmids at 8:1 of N/P ratio (PEI nitrogen: DNA phosphate ratio, based on the recognition that $1 \mu \mathrm{l}$ of PEl stock solution contains $10 \mathrm{nmol}$ of amine nitrogen and $1 \mu \mathrm{g}$ of DNA contains $3 \mathrm{nmol}$ of phosphate [10]). The complexes incubated for 20-30 mins at room temperature and stored in $4^{\circ} \mathrm{C}$. Electrophoresis was carried out for $40 \mathrm{~min}$ at $80 \mathrm{Vs}$.

\section{Cell culture}

The MCF-7 were obtained from China Center for Type Culture Collection (CCTCC) and incubated in Dulbecco's modified Eagle's medium (DMEM, Gibco, Invitrogen Corporation, Grand Island, NY, USA) with 10\% fetal bovine serum (FBS, Gibco, Invitrogen Corporation, Grand Island, NY, USA) and $100 \mathrm{U} /$ $\mathrm{ml}$ penicillin, $100 \mu \mathrm{g} / \mathrm{ml}$ streptomycin, at $37^{\circ} \mathrm{C}$ in a humidified environment of $5 \% \mathrm{CO}_{2}$ and $95 \%$ air.

\section{UTMD protocol}

After reaching $80-90 \%$ confluence, MCF-7cells were harvested before each experiment by $0.25 \%$ trypsin digestion. Cells were then centrifuged (1000 g, 6 min, model GS-15R, Beckman Coulter, Fullerton, CA) and resuspended in DMEM media (300 $\mu \mathrm{l} / \mathrm{well}$ ) to a concentration of $10^{6} \mathrm{cell} / \mathrm{ml}$, as determined by a Coulter Multisizer II (Beckman Coulter) as detailed previously [3]. The suspension of SonoVue microbubbles (Bracco Research, Switzerland) were reconstituted before use by injecting 5 $\mathrm{ml}$ of $0.9 \%$ saline solution. Before the experiments, PEI/DNA complexes $(1 \mu \mathrm{g} / \mathrm{well})$ were gently agitated with cell suspension for $30 \mathrm{~min}$ at room temperature. Before ultrasound exposure, SonoVue microbubbles $(5 \mu \mathrm{g} / \mu \mathrm{l})$ were gently added into well.

All UTMD experiments were performed in a test chamber filled with water and the transducer (Accusonic, Metron Medical Australia Pty. Ltd) was held in a positioning device at the base of the tank as detailed previously [3]. The culture plate was placed on the center of the transducer. Culture plate was covered with the lid to prevent from being polluted by surrounding environment. All operations were performed in the sterile decontamination bench. To prevent the nearby well being affected by ultrasound irradiation, cells were planted in only six wells of 24-well culture plates. During ultrasound irradiation, the plate was moved slowly, sticking closely to the transducer surface. On completion of the exposure, the plates were removed from the tank, wiped dry. The plates were incubated for $8 \mathrm{~h}$ at $37^{\circ} \mathrm{C}$ in a $5 \% \mathrm{CO}_{2}$ incubator, supplemented with $800 \mu$ l of complete media and then incubated to allow for gene expression.

\section{Experimental grouping}

Experiment for parameters optimized was performed as followed: ultrasonic intensity was set to four grades $(0.4 \mathrm{~W} /$ $\mathrm{cm}^{2}, 1.0 \mathrm{~W} / \mathrm{cm}^{2}, 1.6 \mathrm{~W} / \mathrm{cm}^{2}$ and $\left.2.2 \mathrm{~W} / \mathrm{cm}^{2}\right)$, the expose time was set to three grades ( $1 \mathrm{~min}, 3 \mathrm{~min}$ and $5 \mathrm{~min}$ ), and the duty cycle (DC) was set to two grades ( $10 \%$ and $20 \%$ ). And the optimal irradiation parameters were determined through detecting the luciferase activity and cell viability.

Analysis of synergy: under the optimal irradiation conditions, the differences of the luciferase activity were compared. at the condition of US or acoustic contrast agent, PEl alone and the combination of them. The experiment was divided into four groups: naked plasmid group, US irradiation + plasmid group, PEI + plasmid group and US irradiation + SonoVue + $\mathrm{PEI}+$ plasmid group.

The influences of transfection parameters, such as plasmid concentration, solvent [Normal saline (NS); Dhank's (DHK); OPTI-MEM (OPTI), Invitrogen Corporation, Grand Island, NY, USA], serum (without serum or added 10\% FBS before radiation, cells were treated just the same as the way without adding serum), the volume of culture media $(300 \mu \mathrm{l}, 500 \mu \mathrm{l}$ and $1000 \mu \mathrm{l}$ ), incubation time ( $30 \mathrm{~min}$ and $2 \mathrm{~h}$ ) and so on, were compared under optimal irradiation conditions. Above each group of experiment was repeated three times.

\section{Testing for cell viability and luciferase activity}

Cell viability detection and gene expression analysis were performed $48 \mathrm{~h}$ after cell culture. Samples were configured, and the cell suspensions were moved 96 well culture plate $(100 \mathrm{ml})$ after treatment, the cell survival was determined using MTT. Absorbance value was determined using microplate reader (Multiskan MK3, Thermo Electron co.). Cell survival=OD value of experimental group/OD value of blank control group $\times 100 \%$. Determination of luciferase activity Cells were incubated for $2 \mathrm{~min}$ with $200 \mu \mathrm{l}$ cell lysates (Promega Corp., Madison, 
WI, USA) after being washed by PBS twice. The solute was moved to a micro centrifuge tube, and homogenized, frozen in liquid nitrogen, and stored at $-80^{\circ} \mathrm{C}$. Cells were defrosted before being determined, and centrifuged at $12,000 \mathrm{~g}$ at room temperature, determined using luciferase assay kit. $20 \mu \mathrm{l}$ lysis supernatant and $80 \mu \mathrm{l}$ luciferase substrate were mixed luciferase activity in the tissue lysate was measured using a lumat LB9507 instrument (Berthold, Bad Wildbad, Germany). $\mathrm{RLU} / \mathrm{mg}$ protein was used as the unit of standardized luciferase activity expression.

\section{Statistical analysis}

Statistical analyses were performed by the SPSS 13.0 software package (SPSS, Inc, Chicago, IL). All values were expressed as mean $\pm S D$. Analysis of variance with $t$ test and analysis of variance (ANOVA) test were used to determine the significance of the difference in a multiple comparison. If the ANOVA was significant, the Tukey's procedure was used as a post hoc test. Differences with a $P$ value of less than 0.05 were considered to be statistically significant.

\section{Results}

\section{Effect of US parameters on cell viability}

$10 \% \mathrm{DC}$ duty ratio, $0.4 \mathrm{~W} / \mathrm{cm}^{2}$ and $1.0 \mathrm{~W} / \mathrm{cm}^{2}$ ultrasonic intensity didn't cause significant damage to cells, the survival rate> $80 \%$ (Table 1). However, cell death was significantly when the ultrasonic intensity were $2.2 \mathrm{~W} / \mathrm{cm}^{2}$ and $1.6 \mathrm{~W} / \mathrm{cm}^{2}$. Increasing irradiation time also has a visible impact on cell viability.

Under the same ultrasonic intensity, the difference of cell viability betweewn being irradiated for $3 \mathrm{~min}$ and irradiated 5 min was not statistically significant $(P>0.05)$. Under the same ultrasonic intensity and irradiated time for $1 \mathrm{~min}$, any two groups between 20\%DC and 10\%DC showed no significant difference $(P>0.05)$. However, there was statistically significant when being irradiated for 3 mins and 5 mins $(P<0.01)$, and the minimum cell viability was $(48.55 \% \pm 4.18 \%)$ when the US exposure intensity was $2.2 \mathrm{~W} / \mathrm{cm}^{2}$ for 5 mins.

\section{Influence of irradiation strategy on the expression of luciferase activity}

Irradiated by $10 \%$ DC for 3 mins, the difference of luciferase activity between $1.0 \mathrm{~W} / \mathrm{cm}^{2}$ and $1.6 \mathrm{~W} / \mathrm{cm}^{2}$ was not significant $\left[\left(15.16 \pm 0.25 \times 10^{6} \mathrm{RLU} / \mathrm{mg}\right.\right.$ protein vs. $(14.26 \pm 0.86) \times 10^{6} \mathrm{RLU} / \mathrm{mg}$ protein, $P>0.05$ ) but both of the luciferase activity were higher than irradiated by $0.4 \mathrm{~W} / \mathrm{cm}^{2}\left[(8.99 \pm 0.55) \times 10^{6} \mathrm{RLU} / \mathrm{mg}\right.$ protein $]$ and $2.2 \mathrm{~W} / \mathrm{cm}^{2}\left[(11.92 \pm 0.89) \times 10^{6} \mathrm{RLU} / \mathrm{mg}\right.$ protein $]$, and the difference was statistically significant $(P<0.01)$. And luciferase gene expression irradiated by $20 \%$ DC was significantly lower than irradiated by $10 \% \mathrm{DC}$ and the difference was significant $(P<0.01)$. As shown in Table 2 , the highest luciferase activity was obtained when the irradiation parameters were set as $1.0 \mathrm{~W} / \mathrm{cm}^{2}$ and $10 \%$ DC for 3 mins, and the difference was statistically significant $(P<0.01)$.
Table 1. Effect of different ultrasound parameters on MCF-7cell viability (\%)

\begin{tabular}{|c|c|c|c|c|}
\hline \multirow{2}{*}{ Group } & \multirow{2}{*}{$\begin{array}{l}\text { Intensity } \\
\left(\mathrm{W} / \mathrm{cm}^{2)}\right)\end{array}$} & \multicolumn{3}{|c|}{ Exposure time (min) } \\
\hline & & 1 & 3 & 5 \\
\hline 1 & 0.4 & $98.94 \pm 1.92$ & $92.36 \pm 2.24^{*}$ & $88.65 \pm 3.28^{\Delta}$ \\
\hline 2 & 1.0 & $92.71 \pm 4.16$ & $87.21 \pm 0.73^{*}$ & $82.43 \pm 1.28^{*}$ \\
\hline 3 & 1.6 & $82.65 \pm 4.00$ *\# & $71.04 \pm 0.39^{* \# \Delta}$ & $65.41 \pm 3.38^{\S \Delta \Delta}$ \\
\hline 4 & 2.2 & $72.65 \pm 2.30^{* \# \star}$ & $60.21 \pm 4.17 * \# \star \Delta$ & $51.13 \pm 3.06^{\S \Delta \nless \Delta}$ \\
\hline
\end{tabular}

Ultrasound condition: $10 \%$ DC (Duty cycle); as compared with group $1,{ }^{*} \mathrm{P}<0.05, \S \mathrm{P}<0.01$; as compared with group $2, \# \mathrm{P}<0.05$, $\Delta \mathrm{P}<0.01$; as compared with group $3, \mathbf{\Delta} \mathrm{P}<0.05, \otimes \mathrm{P}<0.01$; as compared with $1 \mathrm{~min}, \circledast \mathrm{P}<0.05, \Delta \mathrm{P}<0.01$.

Table 2. Influence of different ultrasound parameters on the expression of luciferase activity (RLU/mg protein, $\times 10^{6}$ ).

\begin{tabular}{cccc}
\hline \multirow{2}{*}{ DC } & \multicolumn{3}{c}{ Exposure time (min) } \\
\cline { 2 - 4 } & 1 & 3 & 5 \\
\hline $10 \%$ & $12.78 \pm 0.17^{\# \mathbf{\Delta}}$ & $15.16 \pm 0.25^{\# \S}$ & $12.41 \pm 0.54^{\#}$ \\
$20 \%$ & $1.13 \pm 0.02^{\star}$ & $0.75 \pm 0.02^{\S}$ & $0.63 \pm 0.00$ \\
\hline
\end{tabular}

Ultrasound condition: $1.0 \mathrm{~W} / \mathrm{cm} 2$; as compared with $20 \% \mathrm{DC}$, $\# \mathrm{P}<0.01$; as compared with $3 \mathrm{~min}, \mathbf{\Delta} \mathrm{P}<0.01$; as compared with 5 $\min , \S \mathrm{P}<0.01$.

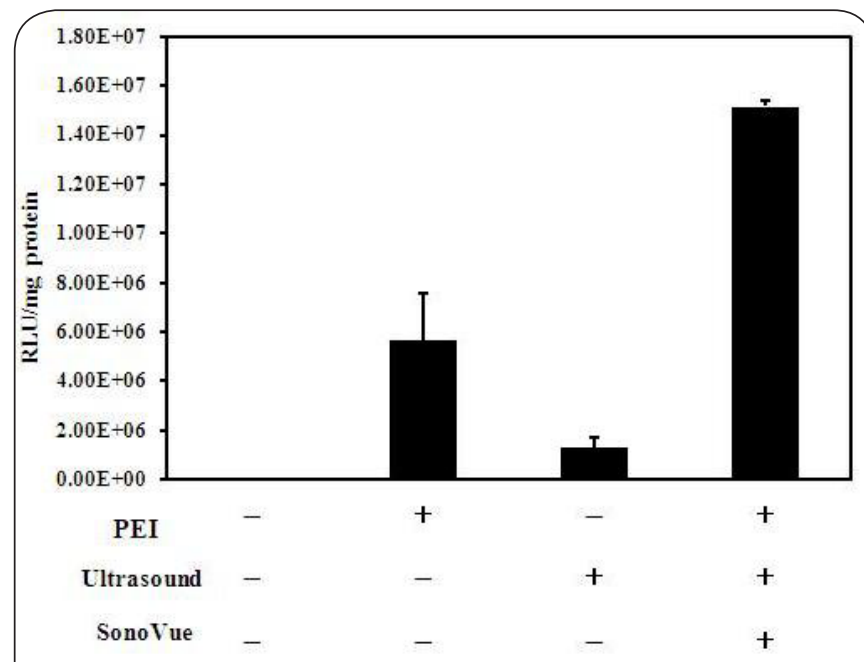

Figure 1. The synergy of ultrasound irradiation and ultrasound contrast agent combined with PEI on the transfection. PEI: Polyethyleneimine. 
The synergy of the combination of US irradiation with contrast agent and PEI in the transfection

As shown in Figure 1, without US irradiation, the luciferase activity of PEl treatment group was higher than the luciferase activity of naked DNA group, and the difference was significant $(P<0.01)$. US irradiation could enhance the luciferase activity of naked DNA, but the increase range of luciferase activity by US irradiation was significantly lower than the increase range of luciferase activity by the combination of US irradiation with contrast agent and PEI $(P<0.01)$. Compared with the naked DNA group, the transfection efficiency in US irradiation group was increased about 25 times, and the transfection efficiency in PEl treatment group was increased about 110 times, while the transfection efficiency in the combination of US irradiation with contrast agent and PEl group was increased about 295 times.

\section{The influence of transfection parameters on US-mediated PEI/DNA transfection}

As shown in Figure 2, the difference of luciferase activity between the different plasmid concentration in the, horizontal wells were not statistically significant $(P>0.05)$. Such as there were no significant difference between $0.25 \mu \mathrm{g} /$ well and $0.5 \mu \mathrm{g} / \mathrm{well}$ in DHK group, $1.0 \mu \mathrm{g} / \mathrm{well}$ and $1.5 \mu \mathrm{g} / \mathrm{well}$ in NS group, as well as $0.5 \mu \mathrm{g} /$ well and $1 \mu \mathrm{g} /$ well in OPTI group, while the differences were significant in other groups $(P<0.05)$. The luciferase activity was increased significantly when the plasmid concentration was increased to $1 \mu \mathrm{g} /$ well $(P<0.01)$, and the increased amplitude in NS group was significantly higher than the increased amplitude in DHK group and OPTI group, the differences were statistically significant $(P<0.01)$.

As shown in Figure 3 , the luciferase activity in $300 \mu$ medium was better than that in $500 \mu \mathrm{l}$ and $1000 \mu \mathrm{l}$ medium significantly (both of $P<0.01$ ). Compared with the activity between $500 \mu \mathrm{l}$ medium and $1000 \mu \mathrm{l}$ medium, the difference was not statistically significant $(P>0.05)$. When the volume of medium was $300 \mu \mathrm{l}$ and the concentraion of plasmid was $1 \mu \mathrm{g} /$ well, the level of luciferase expression was higher, but it was not obvious when the medium volume were $500 \mu \mathrm{l}$ and $1000 \mu \mathrm{l}$.

When the plasmid concentration was $0.5 \mu \mathrm{g} /$ well or $1 \mu \mathrm{g} /$ well, the luciferase activity was significantly lower for 30 mins incubation of PEI/DNA and cells than that for $2 \mathrm{hrs}$ incubation, and the difference was significant $(P<0.01)$. When the plasmid concentration was increased to $2.5 \mu \mathrm{g} /$ well, the difference was not statistically significant with the same medium volume (group1 vs. group3, $P=0.569$ ). Once the serum exists, under the same condition, the difference was not significant with the plasmid concentration of $0.5 \mu \mathrm{g} / \mathrm{well}$, but the luciferase activity difference was statistically significant with higher plasmid concentration $(P<0.01)$.

\section{Discussion}

PEl, which is a cationic polymer, can be used as an intracellular buffer system to inhibit the function of intracellular enzymes,

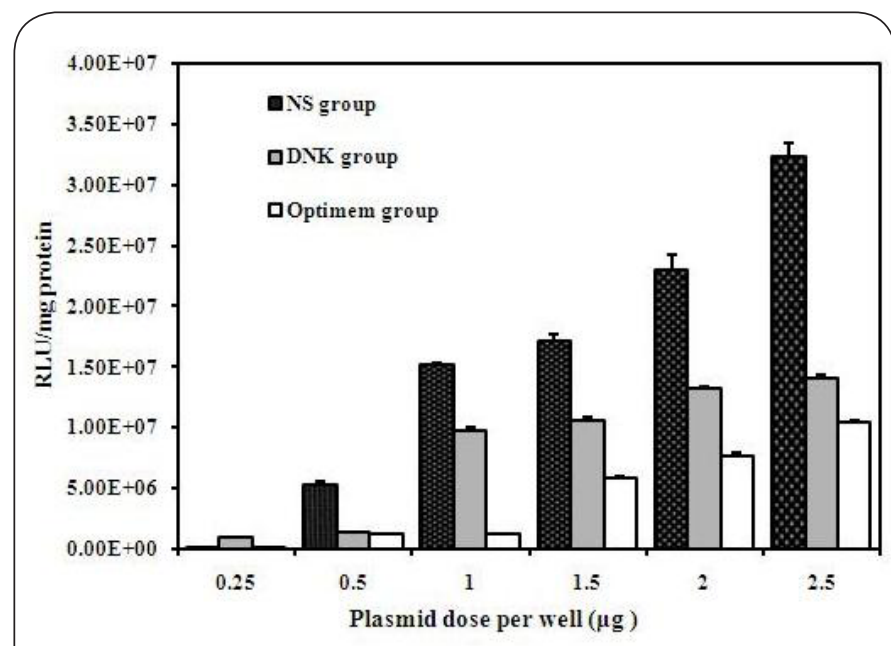

Figure 2. The influence of medium and plasmid concentration on luciferase activity. Ultrasound condition: $1.0 \mathrm{~W} / \mathrm{cm}^{2}, 3 \mathrm{~min}$, $10 \% \mathrm{DC}$; incubation time (30min); the volume of culture media $(300 \mu l)$; without serum.

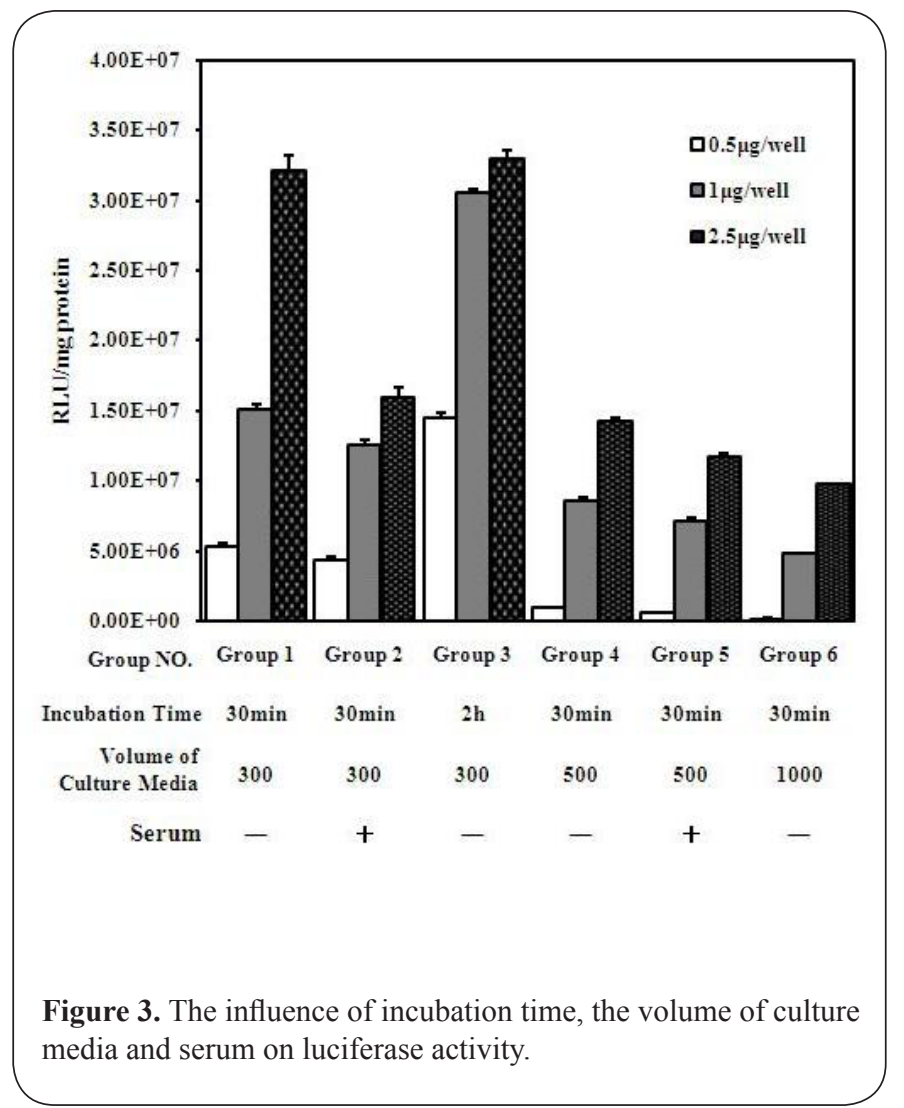


avoid the plasmid DNA from being degraded, resulting in improvement of transfection efficiency, and has been successfully applied in different parts in vivo [11]. It has been shown that ultrasonic cavitation can increase the transmission of DNA or synergistically improve gene transfection in coordination with other reagents such as cationic liposomes $[12,13]$. During the ultrasonic irradiation, DNA complexed with cationic polymers and lipids could increase the stability of plasmid DNA [14]. In addition, both US irradiation and PEI can increase the transfection efficiency, and accompanied with cell death $[2,15,16]$. Significant cell death is unacceptable, so increased transfection efficiency and cell death should achieve to a reasonable balance. Therefore, this study tries to combine US irradiation and contrast agent with PEI as well as optimize different parameters of US irradiation and transfection. The results showed that, this method could increase DNA transfection effectively and synergistically.

The increase of intracellular transport induced by US irradiation was due to the formation of nano or micron membrane pore [17]. Appropriate US exposure could increase the cell membrane reversibility and transient permeability, without any cell lysis or injury. The longer the US irradiation time, the greater the intensity or the higher the DC, the lower cell viability and it can cause significant cell damage or even death, which was the main reason of the reduction of luciferase activity.

The combination of US irradiation with contrast agent and PEl has a synergy, rather than additive effect. Its transfection efficiency was higher than other single method used. The cotransfection method could effectively reduce the dose of US exposure and the amount of PEl. First of all, the mechanism of the increase of transfection efficiency is related to ultrasonic cavitation, and also may involve in a variety of other factors. Microbubble rupture induced by ultrasound irradiation can promote the plasmid DNA uptake and adsorbing by tumor cells, and enhance gene transfer through increasing the PEI/DNA uptake; other effects such as radiation force and acoustic streaming, can promote tumor cells transfection. The microbubbles attached to the cell membrane can interact with the membrane, cascades cell signaling, which is also in favour of improving transfection efficiency.

Considering from mechanics and ultrasound physics, ultrasonic field can increase the collision probability between target cells and PEI/DNA complexes when MCF-7 cells are made into single cell suspension. The course of PEI/DNA complexes uptaked by cells is a slow process. When PEI/DNA complexes are added into the medium, with a lower plasmid concentration, US irradiation for a short time does not benefit to improve transfection efficiency. It is because it took some time for the complexes to interact with membrane. If the interaction between complexes and cells is not complete, US irradiation will not improve gene transfer effectively and synergistically. However, when plasmid concentration is high enough, cells could uptake enough DNA plasmid and the incubation effect will be less important. Other studies have also shown that $[12,13]$, pre-incubation prior to US irradiation was benefit to improving the transfection efficiency of liposome/ DNA complex.

For better understanding the mechanism of synergy when US combined with PEl, we studied the effect of culture medium volume on gene expression. Although many studies [4-6] used cell suspension for ultrasonic irradiation, there are little studies reported the correlation between culture medium volume and transfection efficiency. With the reduction of medium volume, the distance of sound wave transmitted is shortened accordingly, and this is in favour of cell transfection. In addition, salt ions in the solvent which is used to dilute PEI/DNA complexes, have a major impact on the formation patterns of the complexes. NS is beneficial for forming effective transfection particles. The study also tested the serum on the transfection efficiency. Though the absolute value of the fluorescence activity was reduced when the serum existed as other modification manners [18], US still could increase the PEI/DNA complexes transfection. The results indicated that this co-transfection method was not influenced by serum, and was expected to be applied in vivo.

\section{Conclusions}

The results showed that, the optimal parameters of US and transfection could significantly improve the transfection efficiency. The combination of US irradiation with contrast agent and PEI has a synergy on transfection efficiency. Relatively lower US irradiation doses and appropriate parameters would significantly increase gene expression. Further research is still needed to clarify the mechanisms by which, such as to analyze the interaction of the contrast agent concentration, type and contrast agent combined with PEl.

\section{Competing interests}

The Authors declare that they have no competing interests.

\section{Acknowledgements}

This work was supported by Research Projects of Guangzhou Education Bureau (NO. 10A242) and by Research Projects of Guangzhou Technology Bureau (12C22021645), by Medical Research Foundation of Guangdong Province (No. A2011279) and by research projects of Guangdong Provincial Population and Family Planning Commission (NO. 20110324), and by research projects of the Science and Technology Bureau of Guangzhou Liwan District (20111213067).

\section{Publication history}

Received: 08-May-2012 Revised: 02-June-2012

Accepted: 04-Sep-2012 Published: 06-Oct-2012

\section{References}

1. Lungwitz U, Breunig M, Blunk T, Gopferich A: Polyethyleniminebased non-viral gene delivery systems. Eur J Pharm Biopharm 2005; 60;(2.);247-66. | Article | PubMed

2. Neu M, Fischer D, Kissel T: Recent advances in rational gene transfer vector design based on poly(ethylene imine) and its derivatives. J Gene Med 2005; 7;(8.);992-1009. I Article I PubMed 
3. Chen Z, Liang K, Xie M, Wang X, Lu Q, Zhang J: Novel ultrasoundtargeted microbubble destruction mediated short hairpin RNA plasmid transfection targeting survivin inhibits gene expression and induces apoptosis of HeLa cells. Mol Biol Rep 2009; 36;(8.);2059-67. | Article | PubMed

4. Larina IV, Evers BM, Esenaliev RO: Optimal drug and gene delivery in cancer cells by ultrasound-induced cavitation. Anticancer Res 2005; 25;(1A.);149-56. I Article I PubMed

5. Zarnitsyn VG, Prausnitz MR: Physical parameters influencing optimization of ultrasound-mediated DNA transfection. Ultrasound Med Biol 2004; 30;(4.);527-38. | Article | PubMed

6. Wang ZX, Wang ZG, Ran HT, Ren JL, Zhang Y, Li Q, et al.: The treatment of liver fibrosis induced by hepatocyte growth factor-directed, ultrasoundtargeted microbubble destruction in rats. Clin Imaging 2009; 33;(6.);454-61. I Article I PubMed

7. Qiu Y, Zhang C, Tu J, Zhang D: Microbubble-induced sonoporation involved in ultrasound-mediated DNA transfection in vitro at low acoustic pressures. J Biomech 2012; 45;(8.);1339-45. | Article | PubMed

8. Lee JL, Lo CW, Ka SM, Chen A, Chen WS: Prolonging the expression duration of ultrasound-mediated gene transfection using PEI nanoparticles. J Control Release 2012; 160;(1.);64-71. | Article | PubMed

9. Shimamura $M$, Sato $N$, Taniyama $Y$, Yamamoto $S$, Endoh $M$, Kurinami $H$, et al.: Development of efficient plasmid DNA transfer into adult rat central nervous system using microbubble-enhanced ultrasound. Gene Ther 2004; 11;(20.);1532-9. | Article | PubMed

10. Jeong JH, Kim SW, Park TG: Biodegradable triblock copolymer of PLGAPEG-PLGA enhances gene transfection efficiency. Pharm Res 2004; 21;(1.);50-4. I Article I PubMed

11. Kichler A, Leborgne C, Coeytaux E, Danos O: Polyethylenimine-mediated gene delivery: a mechanistic study. J Gene Med 2001; 3;(2.);135-44. I PubMed

12. Lawrie A, Brisken AF, Francis SE, Cumberland DC, Crossman DC, Newman $\mathrm{CM}$ : Microbubble-enhanced ultrasound for vascular gene delivery. Gene Ther 2000; 7;(23.);2023-7. I Article I PubMed

13. Feril LB, Jr., Ogawa R, Kobayashi H, Kikuchi H, Kondo T: Ultrasound enhances liposome-mediated gene transfection. Ultrason Sonochem 2005; 12;(6.);489-93. I Article I PubMed

14. Kuo JH, Jan MS, Sung KC: Evaluation of the stability of polymer-based plasmid DNA delivery systems after ultrasound exposure. Int J Pharm 2003; 257;(1-2.);75-84. | Article | PubMed

15. Moghimi SM, Symonds P, Murray JC, Hunter AC, Debska G, Szewczyk A: A two-stage poly(ethylenimine)-mediated cytotoxicity: implications for gene transfer/therapy. Mol Ther 2005; 11;(6.);990-5. I Article I PubMed

16. Feril LB, Jr., Kondo T: Biological effects of low intensity ultrasound: the mechanism involved, and its implications on therapy and on biosafety of ultrasound. J Radiat Res 2004; 45;(4.);479-89. I Article I PubMed

17. Schlicher RK, Radhakrishna H, Tolentino TP, Apkarian RP, Zarnitsyn $\mathrm{V}$, Prausnitz MR: Mechanism of intracellular delivery by acoustic cavitation. Ultrasound Med Biol 2006; 32;(6.);915-24. | Article | PubMed

18. Tang GP, Zeng JM, Gao SJ, Ma YX, Shi L, Li Y, et al.: Polyethylene glycol modified polyethylenimine for improved CNS gene transfer: effects of PEGylation extent. Biomaterials 2003; 24;(13.);2351-62. | Article | PubMed

\section{Citation:}

Chen ZY, Qiu RX, Sun XF, Liang K, Zhang JS, Lin $\mathrm{Y}$ and Yang F: The optimization of transfection in MCF-7 cells combining ultrasound irradiation with contrast agent and polyethyleneimine. journal of Cancer Therapeutics and Research 2012, 1:26. http://dx.doi.org/10.7243/2049-7962-1-26 